\title{
HUBUNGAN POLA KONSUMSI IKAN LAUT DENGAN KARIES GIGI PADA NELAYAN DI PELABUHAN PERIKANAN PASONGSONGAN TAHUN 2020
}

\author{
Nuris Tri Septiarsih ${ }^{1}$ Sunomo Hadi ${ }^{2}$ Sri Hidayati ${ }^{3}$ \\ ${ }^{123}$ Jurusan Keperawatan Gigi Politeknik Kesehatan Kementerian Kesehatan Surabaya \\ Email : nuris.septi11@gmail.com
}



Kata Kunci :

Pola konsumsi ikan;

karies gigi; nelayan.

\begin{abstract}
ABSTRAK
Karies merupakan salah satu penyakit gigi dan mulut yang prevalensinya di Indonesia masih cukup tinggi. Karies gigi adalah penyakit jaringan gigi yang ditandai dengan kerusakan jaringan, dimulai dari permukaan gigi (ceruk, fisura, dan daerah interproksimal) meluas kearah pulpa. Nelayan biasanya pergi melaut di sore hari dan pulang di pagi hari, terkadang beberapa hari mereka berada di laut sehari semalam. Hal ini yang menyebabkan perhatian terhadap kebersihan gigi dan mulut menjadi kurang. Kebersihan gigi dan mulut apabila kurang terjaga maka dapat meningkatkan terjadinya karies gigi. Masalah dalam penelitian ini yaitu tingginya indeks karies gigi pada nelayan di Pelabuhan Perikanan Pasongsongan Tahun 2020. Penelitian ini bertujuan untuk mengetahui adanya hubungan pola konsumsi ikan dengan karies gigi pada nelayan di Pelabuhan Perikanan Pasongsongan. Jenis penelitian ini merupakan penelitian analitik cross sectional. Jumlah sampel dalam penelitian ini adalah 82 orang. Metode pengumpulan data dengan cara observasi dan kuesioner. Teknik analisis data menggunakan uji chi-square (uji altenatif Pearson Correlation) dengan hasil nilai signifikan 0,827 . Hasil penelitian yaitu tidak ada hubungan pola konsumsi ikan dengan karies gigi pada nelayan di Pelabuhan Perikanan Pasongsongan tahun 2020.

ABSTRACT
Caries is a dental and oral disease whose prevalence in Indonesia is
still quite high. Dental caries is a disease of dental tissue
characterized by tissue damage, starting from the surface of the teeth
(niches, fissures, and interproximal regions) extending towards the
pulp. Fishermen usually go out to sea in the afternoon and go home
in the morning, sometimes some days they are at sea one day and
night. This is what causes less attention to oral hygiene. Oral and
dental hygiene if not maintained can increase the occurrence of
dental caries. The problem in this study is the high dental caries
index in fishermen in Pasongsongan Fisheries Port in 2020. This
study aims to determine the relationship between fish consumption
patterns and dental caries in fishermen in Pasongsongan Fisheries
Port. This type of research is a cross sectional analytic study. The
number of samples in this study were 82 people. Data collection
methods by observation and questionnaire. Data analysis techniques
used the chi-square test (Pearson Correlation alternative test) with a
significant value of 0.827 . Conclusion: The results of the study are
that there is no correlation between the relationship of sea fish
consumption patterns with dental caries in fisheries port
pasongsongan, 2020 .
\end{abstract}

Key word:

Keywords: Fish

consumption

patterns; dental caries;

fishermen. 


\section{PENDAHULUAN}

Pembangunan kesehatan diarahkan untuk meningkatkan kesadaran, kemauan, dan kemampuan hidup sehat bagi setiap orang agar peningkatan derajat kesehatan masyarakat yang setinggi-tingginya dapat terwujud. Kesehatan gigi dan mulut adalah kesehatan sehat dari jaringan keras dan jaringan lunak gigi serta unsur-unsur yang berhubungan dengan rongga mulut, yang memungkinkan individu makan, berbicara, dan berinteraksi sosial tanpa disfungsi, gangguan estetik dan ketidaknyamanan karena adanya penyakit penyimpangan oklusi dan kehilangan gigi sehingga mampu hidup produkti secara sosial dan ekonomi (Kemenkes RI, 2015)

Wilayah Kabupaten Sumenep terdiri dari daratan dan kepulauan. Kabupaten Sumenep memiliki 126 pulau (sesuai dengan hasil sinkronisasi luas Kabupaten Sumenep Tahun 2002), tersebar membentuk gugusan pulau-pulau baik berpenghuni (48 pulau) maupun tidak berpenghuni (78 pulau). Luas perairan umum $\pm 121.12 \mathrm{Ha}$ dan mengahsilkan produksi sebesar 77.65 ton per tahun. Jenis ikan hasil tangkapan berupa ikan layang, ikan teri, ikan tongkol, udang dll. Hal ini didukung oleh banyaknya hasil tangkapan ikan layang dari daerah Pasongsongan. Pasongsongan merupakan desa yang berada di dalam lingkup kecamatan Pasongsongan dan termasuk wilayah paling barat di Kabupaten Sumenep. Sehubungan dengan keadaan sosial ekonomi, sebagian besar penduduknya adalah melaut (nelayan) dan sebagian kecil pegawai negeri, guru-guru pendidikan, pertanian, swasta, wiraswasta, pelajar/mahasiswa, dan lainnya.

Nelayan adalah suatu kelompok masyarakat yang kehidupannya tergantung pada hasil laut. Masyarakat neayan merupakan saah satu bagian masyarakat Indonesia yang hidup dengan mengelola potensi sumberdaya perikanan. Masyarakat yang hidup, tumbuh dan berkembang di kawasan pesisir yang mengolah hasil dari mata pencaharian mereka untuk mempertahankan hidup (Fargomeli, 2014)

Ikan memiliki kandungan gizi yang sangat tinggi dan berfungsi membantu pertumbuhan gigi dan tulang. Salah satunya ikan teri, ikan teri merupakan makanan kualitas tinggi karena seluruh bagian tubuhnya dapat dikonsumsi. Tulang ikan teri banyak mengandung protein dan tinggi kalsium. Tiap 100 gram teri segar mengandung energi $77 \mathrm{kkal}$; protein 16 gram; lemak 1,0 gram; kalsium $500 \mathrm{mg}$; phospor $500 \mathrm{mg}$; besi 1,0 mg; Vit A 47; dan Vit B 0,1 mg. Kandungan ikan teri baik segar maupun kering lebih tinggi dibanding dengan ikan lainnya (Aryati dan Darmayanti, 2014)

Ikan laut yang banyak di konsumsi masyarakat nelayan memiliki kandungan mineral contohnya fluor. Adanya fluor yang di ikat email gigi menyebabkan proses mineralisasi pada gigi lebih cepat sehingga dapat menekan angka karies (Fitriyanti dkk., 2012)

Karies merupakan salah satu penyakit di gigi dan mulut yang prevalensinya di Indonesia masih cukup tinggi. Karies gigi adalah penyakit jaringan gigi yang ditandai dengan kerusakan jaringan, dimulai dari permukaan gigi (ceruk, fisura, dan daerah interproksimal) meluas kearah pulpa. Karbohidrat yang tertinggal di dalam mulut dan mikroorganisme, merupakan penyebab dari karies gigi (Tarigan, 2012) 
Upaya kesehatan gigi perlu ditinjau dari aspek lingkungan, pendidikan, kesadaran masyarakat dan penanganan kesehatan termasuk pencegahan dan perawatan. Aspek tersebut saling berhubungan dan saling mempengaruhi, baik cara pecegahan dan perawatan gigi masyarakat (upaya kesehatan gigi masyarakat) maupun keadaan kesehatan gigi masyarakat.

\section{METODE PENELITIAN}

Jenis penelitian yang digunakan adalah analitik dengan pendekatan cross sectional. Sasaran dalam penelitian ini adalah masyarakat nelayan yang berusia 35-44 tahun di Pelabuhan Perikanan Pasongsongan Dusun Lebak Kecamatan Pasongsongan dengan jumlah 82 responden.

Penelitian ini dilakukan pada bulan September 2019 sampai Mei 2020. Penelitian ini telat memiliki persetujuan komisi etik dengan nomor: 203/KEPKPoltekkes_Sby/V/2020.

Pengumpulan data kuesioner masyarakat nelayan dengan cara berkoordinasi dengan pegawai Pelabuhan Perikanan Pasongsongan Dusun Lebak Kecamatan Pasongsongan, mengumpulkan masyarakat nelayan, sebelum kegiatan pengisian kuesioner, peneliti memberikan pengarahan, setelah itu peneliti dan responden melakukan proses wawancara.

Pengumpulan data Indeks Karies Gigi masyarakat nelayan dengan cara berkoordinasi dengan pegawai Pelabuhan Perikanan Pasongsongan Dusun Lebak Kecamatan Pasongsongan, mengumpulkan masyarakat nelayan, Langkah Pemeriksaan (DMFT).Persiapan peralatan diagnostik , seperti sonde, kaca mulut, pinset, dan eksavator Responden satu per satu dilakukan pemeriksaan status kesehatan gigi dan mulut dengan penilaian DMF-T. Hasil penilaian DMF-T dicatat pada lembar pemeriksaan dan memeriksa kembali kebenarannya.

Frekuensi pola konsumsi ikan laut masyarakat nelayan yakni memberikan gambaran mengenai jenis, frekuensi dan jumlah bahan pangan yang dimakan tiap hari oleh satu orang dengan kriteria penilaian yakni, 1-2x/Minggu $=$ Jarang, 3-5x/Minggu $=$ Kadang-kadang, dan $>5 \mathrm{x} /$ Minggu $=$ Sering.

Indeks DMF-T menggambarkan penilaian status kesehatan gigi dan mulut dalam hal karies gigi permanen dengan kriteria penilaian $0,0-2,6=$ rendah, 2,7 $-4,4=$ sedang, dan $>4,5=$ Tinggi. 


\section{HASIL DAN PEMBAHASAN}

Tabel 1 : Distribusi Frekuensi Pola Konsumsi Ikan Pada Nelayan Pelabuhan Perikanan Pasongsongan Tahun 2020

\begin{tabular}{cccc}
\hline No & Kategori & Frekuensi & Persentase \\
\hline 1 & Jarang & 12 & $14,6 \%$ \\
2 & Kadang & 27 & $32,9 \%$ \\
3 & Sering & 43 & $52,5 \%$ \\
\hline & Total & 82 & $100,0 \%$ \\
\hline
\end{tabular}

Berdasarkan Tabel 1: Diketahui bahwa hasil konsumsi ikan pada nelayan yang sering mengkonsumsi ikan hampir sebagian besar sebesar 52,5\%

Tabel 2 : Hasil Pengumpulan Data Karies Gigi Pada Nelayan Pelabuhan Perikanan Pasongsongan tahun 2020

\begin{tabular}{cccc}
\hline No & Kategori & Frekuensi & Persentase \\
\hline & Rendah & 6 & $7,3 \%$ \\
2 & Sedang & 20 & $24,4 \%$ \\
3 & Tinggi & 56 & $68,3 \%$ \\
3 & Total & 82 & $100,0 \%$ \\
\hline
\end{tabular}

Berdasarkan Tabel 2 : Diketahui bahwa hasil karies gigi pada nelayan yang paling banyak dengan kategori tinggi sebesar $68,3 \%$

Tabel 3 : Hubungan Pola Konsumsi Ikan dengan Indeks Karies Gigi Pada Nelayan Pelabuhan Perikanan Pasongsongan tahun 2020

\begin{tabular}{ccccc}
\hline Kategori Pola & \multicolumn{3}{c}{ Kategori Indeks Karies Gigi } & \multirow{2}{*}{ Total } \\
\cline { 2 - 4 } Konsumsi Ikan & Rendah & Sedang & Tinggi & 12 \\
\hline Jarang & 0 & 3 & 9 & 27 \\
kadang & 4 & 5 & 18 & 43 \\
Sering & 2 & 12 & 29 & 82 \\
\hline total & 6 & 20 & 56 & \\
\hline
\end{tabular}

Berdasarkan Tabel 3 : Hubungan kedua variabel antara pola konsumsi ikan dengan indeks karies gigi pada Nelayan Pasongsongaan tahun 2020. Responden dengan kategori frekuensi pola konsumsi ikan yang paling banyak dengan kategori sering yaitu 43 orang, sedangkan responden dengan kategori indeks karies gigi yang paling banyak dengan kategori tinggi yaitu 56 orang. 
Home page: http://ejurnal.poltekkestasikmalaya.ac.id/index.php/jikg/index

Tabel 4 : Uji Analisis Hubungan Pola Konsumsi Ikan dengan Indeks Karies Gigi Pada Nelayan Pelabuhan Perikanan Pasongsongan tahun 2020

\begin{tabular}{cccccc}
\hline \multirow{2}{*}{$\begin{array}{c}\text { Kategori Pola } \\
\text { Konsumsi Ikan }\end{array}$} & \multicolumn{2}{c}{ Kategori Indeks Karies Gigi } & \multirow{2}{*}{ Total } & \\
\cline { 2 - 4 } & Rendah & Sedang & Tinggi & & \\
\hline Jarang & 0 & 3 & 9 & 12 & 0,827 \\
Kadang & 4 & 5 & 18 & 27 & \\
Sering & 2 & 12 & 29 & 43 & \\
\hline Total & 6 & 20 & 56 & 82 & \\
\hline
\end{tabular}

Hasil analisis data Chi-Square (uji altenatif Pearson Correlation) menunjukan bahwa hasil analisis uji signifikansi data hubungan antara pola konsumsi ikan dengan karies gigi pada nelayan pelabuhan perikanan Pasongsongan adalah 0,827. Hal ini berarti 0,827 lebih besar dari nilai signifikansi $(\alpha)$ yang telah ditetapkan yaitu 0,05 . Maka dari itu $\mathrm{H}_{0}$ diterima dan $\mathrm{H}_{1}$ ditolak, sehingga kedua varibel tersebut tidak ada hubungan. Dengan demikian tidak ada hubungan antara pola konsumsi ikan dengan indeks karies gigi pada nelayan pelabuhan perikanan Dusun Lebak Desa Pasongsongan Sumenep tahun 2020.

\section{PEMBAHASAN}

\section{Pola Konsumsi Ikan Pada Nelayan Pelabuhan Perikanan Pasongsongan tahun 2020}

Berdasarkan hasil penelitian di dapatkan banyak masyarakat khususnya nelayan memiliki pola konsumsi ikan dengan kategori sering. Faktor ini dikarenakan adanya produksi ikan laut disana yang sangat berlimpah sehingga dari segi biaya relatif terjangkau atau mudah didapatkan. Hasil kuesioner juga menunjukkan bahwa pola konsumsi ikan pada nelayan tergolong sering. Hal ini sesuai teori Prianto (2005) yang menyatakan bahwa masyarakat yang di dominasi oleh usaha perikanan yang hidup di pemukiman pesisir memiliki karakteristik secara sosial ekonomis sangat terkait dengan sumber perekonomian dari wilayah laut (Prianto, 2005 cit Sukmana, 2016)

Menurut Notoatmodjo (2014), faktor pengetahuan tentang konsumsi ikan juga berpengaruh. Pengetahuan seseorang dipengaruhi oleh pengalaman yang berasal dari berbagai sumber, misalnya media massa, media elektronik, buku petunjuk, petugas kesehatan, media poster kerabat dekat dan sebagainya. Pengetahuan ini dapat membentuk keyakinan tertentu sehingga seseorang berperilaku sesuai keyakinan tersebut. Pada masyarakat nelayan sebagian besar pengetahuan mengenai konsumsi ikan yang baik bagi kesehatan gigi memiliki pengetahuan yang kurang. Hal ini, dapat ditemui ketika peneliti menanyakan kandungan gizi ikan untuk kesehatan gigi pada masyarakat masih belum mengerti. Pengetahuan merupakan domain yang sangat penting dalam membetuk tindakan seseorang (Notoatmodjo, 2014)

\section{Indeks Karies Gigi Pada Nelayan Pelabuhan Perikanan Pasongsongan tahun 2020}

Berdasarkan hasil penelitian di dapatkan masyarakat nelayan memiliki karies gigi dengan kategori tinggi. Masih tingginya angka indeks karies gigi ini dikarenakan 
perilaku masyarakat yang tidak diimbangi dengan perilaku menjaga kesehatan gigi dan mulutnya seperti menggosok gigi dengan waktu dan cara yang tepat. Sebagian besar masyarakat juga cenderung menggosok giginya pada waktu mandi saja. Sedangkan waktu yang tepat untuk menggosok gigi adalah pagi setelah sarapan dan malam sebelum tidur. Jika ditinjau dari teori Blum cit. Notoatmodjo (2014) tidak hanya ditentukan oleh perilaku tetapi juga ada faktor lain yang penting yaitu lingkungan (environment), pelayanan kesehatan (health service) dan keturunan (heredity).

Faktor lingkungan (environment) yang paling penting pengaruhnya. Lingkungan yang dimaksud adalah orang-orang yang berada di lingkungan tersebut dekat dengan pasar dan menjual makanan-makanan kariogenik contohnya lemper, donat dan sebagainya. Sehingga nelayan juga mengkonsumsi makanan yang berkariogenik yang dapat menyebabkan karies gigi. Kesehatan lingkungan pada hakikatnya adalah suatu kondisi atau keadaan lingkungan yang optimum sehingga berpengaruh positif terhadap terwujudnya status kesehatan yang optimal pula. Lingkungan sangat berperan dalam pertumbuhan dan perkembangan anak. Definisi lain dikemukakan oleh WHO (World Health Organization) yaitu keseimbangan ekologi yang harus ada antara manusia dan lingkungan agar dapat menjamin keadaan sehat dari manusia.

\section{Hubungan Pola Konsumsi Ikan dengan Indeks Karies Gigi Pada Nelayan Pelabuhan Perikanan Pasongsongan tahun 2020}

Hasil penelitian didapatkan tidak ada hubungan antara pola konsumsi ikan laut dengan karies gigi pada pada nelayan pelabuhan perikanan pasongsongan tahun 2020 karena ikan laut yang mengandung mineral contohnya fluor yang dapat diikat email gigi dapat menekan angka karies serta adanya karies gigi pada nelayan disebabkan karena tidak diimbanginya menjaga kesehatan gigi dan mulut. Penelitian ini sejalan dengan hasil penelitian yang dilakukan oleh Sadika (2012) bahwa tidak ada pengaruh kebiasaan mengkonsumsi ikan laut terhadap prevalensi karies gigi yang diukur dengan indeks karies pada masyarakat di Desa Wringin Anom Kecamatan Asembagus Kabupaten Situbondo. Meskipun sering mengkonsumsi ikan laut, tetapi tidak ada pengaruhnya terhadap prevalensi karies gigi. Faktor lain yang mempengaruhi yaitu masih rendahnya tingkat kesadaran penduduk untuk melakukan pemeriksaan ke dokter gigi dan tingkat kebersihan mulutnya tergolong rendah karena kurangnya pengetahuan nelayan akan pentingnya menjaga kesehatan gigi dan mulut.

Penduduk harus menjaga kebersihan rongga mulutnya agar terhindar dari masalah kesehatan gigi dan mulut. Perilaku sehat seseorang diwujudkan dalam tindakan untuk memelihara dan menjaga kesehatannya, termasuk pencegahan penyakit dan perawatan kebersihan diri. Apabila perilaku sehat tersebut tidak dilakukan oleh seseorang maka tingkat kesehatannya juga akan menurun.

Berdasarkan hasil penelitian pola konsumsi ikan laut pada nelayan pelabuhan perikanan pasongsongan tahun 2020, maka didapatkan hasil pola konsumsinya sering. Namun, pada hasil angka indeks karies gigi masih tergolong kategori tinggi. Karena tidak diimbangi dengan memelihara kesehatan gigi dan mulut seperti menggosok gigi dengan cara dan waktu yang tepat sehingga inilah yang mungkin menjadi faktor penyebab tingginya angka indeks karies gigi pada nelayan pelabuhan perikanan pasongsongan tahun 2020. 


\section{KESIMPULAN}

\section{SIMPULAN}

Berdasarkan hasil penelitian tentang hubungan pola konsumsi ikan dengan karies gigi pada nelayan pelabuhan perikanan pasongsongan tahun 2020 dapat disimpulkan bahwa :

1. Rata-rata sebagian besar nelayan di Pelabuhan Perikanan Pasongsongan Tahun 2020 memiliki pola konsumsi ikan dengan kategori sering.

2. Rata-rata nilai indeks karies gigi nelayan di Pelabuhan Perikanan Pasongsongan Tahun 2020 termasuk dalam kategori tinggi.

3. Tidak ada hubungan antara pola konsumsi ikan dengan karies gigi pada nelayan di Pelabuhan Perikanan Pasongsongan Tahun 2020.

\section{SARAN}

Berdasarkan hasil kesimpulan, maka dapat diberikan saran sebagai berikut :

1. Bagi Petugas Kesehatan diharapkan agar membentuk kader kesehatan gigi di masyarakat dengan pembinaan untuk lebih meningkatkan pengetahuan dan lebih peduli dalam menjaga kesehatan gigi dan mulutnya. Dan memberikan penyuluhan tentang cara menjaga kesehatan gigi dan mulut yang baik. Penyuluhan dilakukan setiap 2 kali dalam 1 bulan.

2. Bagi Peneliti Lain diharapkan skripsi ini dapat dijadikan sebagai informasi untuk melanjutkan penelitian oleh peneliti lain dengan meneliti tentang pola konsumsi ikan serta apa saja faktor lain yang menyebabkan tingginya angka karies gigi.

\section{DAFTAR PUSTAKA}

Alhamda, S. (2011) 'Status Kebersihan Gigi dan Mulut dengan Status Karies Gigi ( Kajian pada Murid Kelompok Umur 12 Tahun di Sekolah Dasar Negeri Kota Bukittinggi )', 27(2), pp. 108-115.

Anindita, Y., Kiswaluyo and Handayani, A. T. W. (2018) 'Hubungan Tingkat Kebersihan Gigi dan Mulut dengan Karies pada Nelayan di Pesisir Pantai Watu Ulo Kabupaten Jember ( The Relationship of Oral Hygiene Levels with Caries in Fishermen at Watu Ulo Coastal Jember District )', e-Jurnal Pustaka Kesehatan, 6(2), pp. 345-350.

Aryati E, E. and Suci Dharmayanti, A. W. (2014) 'MANFAAT IKAN TERI SEGAR (Stolephorus sp) TERHADAP PERTUMBUHAN TULANG DAN GIGI', ODONTO : Dental Journal, 1(2), p. 52. doi: 10.30659/odj.1.2.52-56.

Fargomeli, F. (2014) 'Interaksi Kelompok Nelayan Dalam Meningkatkan Taraf Hidup Di Desa Tewil Kecamatan Sangaji Kabupaten Maba Halmahera Timur', jurnal Acta Diurna, 3(3), p. 4.

Fitriyanti, A., Susilowati, A. and N.A. Darjono, U. (2014) 'Perbedaan Pola Konsumsi Ikan Dan Status Kesehatan Gigi Dan Mulut Pada Anak Usia Sekolah Dasar (712 Th) Di Daerah Pesisir Dan Non Pesisir Kabupaten Jepara Tahun 2012', 
ODONTO : Dental Journal, 1(1), p. 6. doi: 10.30659/odj.1.1.6-10.

Ismiyanti, D. (2013). Hubungan Antara Pola Konsumsi Protein Dan Kesegaran Jasmani Dengan Angka Kesakitan Pada Siswa SD NEGERI KARTASURA 1 (pp. 1-21). pp. 1-21. Surakarta: Universitas Muhammadiyah Surakarta.

Kurniawati, N. (2005). Perilaku Konsumsi Ikan Pada Wanita Dewasa Di Wilayah Pantai Dan Bukan Pantai Propinsi Daerah Istimewa Yogyakarta. Bogor: Institusi Pertanian Bogor.

Notoatmodjo, 2014. Promosi Kesehatan Teori dan Aplikasi. Rineka Cipta. Jakarta. Hal. 104-108

Sadika, L.G, 2012. Pengaruh Kebiasaan Mengkonsumsi Ikan Laut Terhadap Prevalensi Karies Gigi Di Desa Wringin Anom Kecamatan Asembagus Kecamatan Situbondo.https://repository.unej.ac.id/handle/123456789/2494

Sukmana, I.B. 2016. Gambaran Karies Dengan Menggunakan DMF-T Pada Masyarakat Pesisir Pantai Kelurahan Takisung Kecamatan Takisung Kabupaten Tanah Laut. Banjarmasin: Fakultas Kedokteran Universitas Lambung Mangkurat. Skripsi. http://ppjp.unlam.ac.id/journal/index.php/dentino/article/570/483. diakses pada April 2020

Tarigan, R. 2012. Karies Gigi. EGC. Jakarta. Hal. 01 